\title{
Jewish settlement plans in Bohemia from the first half of the 18th century
}

\author{
Jiř́ DROZDA ${ }^{\mathrm{a}}{ }^{*}$, Šárka STEINOVÁ $^{\mathrm{b}}$, Filip PAULUS ${ }^{\mathrm{b}}$ \\ ${ }^{a}$ Research Institute of Geodesy, Topography and Cartography,v.v.i., jiri.drozda@vugtk.cz \\ ${ }^{b}$ National Archives Czech Republic, sarka.steinova@nacr.cz, filip.paulus@nacr.cz \\ * Corresponding author
}

\begin{abstract}
:
Only few maps or plans from the first half of 18th century showing towns and villages in detail have survived up to present days. So the file of 98 plans and sketches of Jewish settlement in Bohemia is really unique treasure. This file has been scattered in several Czech and Moravian archives. Researchers of the National Archives and the Research Institute of Geodesy, Topography and Cartography managed to collect those maps, analyze, interpret and digitalized them. Maps itself are very different due to they were created by various authors with varying cartographic knowledge and experience. File represents a unique collection of plans that have been prepared in the course of one year (1727) as the result of the imperial translocation rescripts. Nowhere else similar set of plans depicting the Jewish population in the villages and cities has exist. The importance of file is also supported by the fact that plans of small villages and/or towns of marginal importance were captured, while plans of larger cities are missing.

The uniqueness of this file is underlined by the fact that file fulfils all criteria fixed by the Czech UNESCO Commission for inclusion in the Registry of Memory of the World. In the year 2019 the National Archives will issue monographs presenting whole set of plans and sketches of Jewish settlement named "Landscape and urban planning on the handwritten plans from 18th century.
\end{abstract}

Keywords: Jews, settlements plans

\section{Introduction}

During the second half of the $17^{\text {th }}$ century and especially during the first half of the $18^{\text {th }}$ century, state interventions against the Jewish population began to intensify. Disagreements emerging from the effort to reduce the Jewish population interfered with the central policy of the state. On the one hand there were the interests of the court chancellery, on the other there were the interests of the chamber and the royal fissure. (Roubík, F.,1931, 1961) The regulation affecting the lives of the population consequently impacted the state's economy and its financial policy. The result of the imperial translocation rescripts of 1727 (a follow-up to the so-called familiar law of 1726) was the mapping of the Jewish settlements in the villages and cities of the Czech Crown Lands. According to a rough estimate, the regulation affected about 30,000 Czech and 20,000 Moravian inhabitants. The stadtholder ordered the creation of maps of the cities and villages in order to establish the distance between Jewish dwellings and catholic churches. (Legnerová, H., 2005) While previous research work focused only on individual plans, in the year 2018 there was an extensive research of whole set of plans, when all portrayed buildings and objects have been identified and compared with Index Sketches of the Stable Cadastre and current aerial imagery. Results of this research are published in interdisciplinary Czech-English monograph "The countryside and urbanism in the 18th century, handwritten plans. Translocation Plans for the Jewish Settlements in the lands of the Czech Crown in 17271728". (Ebelová, I., Paulus, F., Steinová, Š. et col.,2019)

\section{The Parameters of Maps and Charts}

Maps of the Czech villages and towns from the beginning of the 18th century showing the Jewish dwellings were first stored at the registry of the Old Czech Administration and from there, thanks to the archivists Jan Josef Klauser and Kajetan Nadherny, they were moved to the Collection of the Old Administration. After the abolition of the Administration, the documents were transferred to the Czech Archives, the Archives of the Ministry of the Interior, and later to the State's Central Archives and, since 2002 they have been stored at the National Archives (the successor organization of the Archives of the Ministry of the Interior).

More specifically we are talking about a set of 98 maps from the year 1727 . The individual maps generally capture the overall picture of a given site or area, with the exact designation of the Jewish dwellings, synagogues, cemeteries, and their position in relation to the churches. 
Part of the maps provides a perspective view, capturing the construction of individual buildings. Maps thus show the variable quality from perfectly executed works to schematic sketches. Specifically, the 41 maps show the characteristics of the view or the image; in 22 of them we find, not only the view, but also the ground plan, and in the remaining 35 maps there is only the ground plan. As for art techniques, we see 7 colored drawings, 2 drawings, 23 drawings created by ink or a pen.

The dimensions of the maps range from $18 \times 12$ to $100 \times$ $37 \mathrm{~cm}$, but most often approximately $25 \times 30$ to $65 \times 45$ $\mathrm{cm}$. The scale is predominantly in the "Prague loket" (ell) or in "sáh" (provincial fathom), which were the basic units of measurement for the given period. The only exceptions are, of course, views where no scale can be used.

Map captions and descriptions are placed at the edge or in the area, depending on the selected paper size. Among the languages individually represented are Latin, Czech (5), and German (88), or in a combination Latin, Czech (8), or Czech, German (2).

The authors of the individual maps and charts were, on the one hand, the land surveyors, military engineers, urban builders, but also city or renowned scribes, or laymen on the other. However, it is important to note that, out of the 103 charts, 34 are unsigned. Among the most represented authors we can find, for example, the land surveyor Jan Josef Trübl (8), the builder from Žatec Tomáš Martin Losche (7), the juratory surveyor Jan Neander (9) and the juratory surveyor Jan Knittl (3). These above-mentioned authors focused on a particular region that had been mandated, or possibly had a personal relationship with. The rest of the group consisted of authors with minimal knowledge in the field of cartography, from whom only individual maps have been preserved, and it is evident from the quality of workmanship of their maps, which was based primarily on their artistic feelings.

\section{The identification of the places}

The first step for methodological processing was to create a database of charts. The range and content of the database was continually being defined during the processing and was therefore being expanded by additional items. The basic data for the charts were taken from catalogs of the collection of maps and charts of the National Archives created in the 70s of the 20th century. The sections of the registration records included: the inventory number, signature, description, author, date, dimensions, and location. The authors of this study subsequently expanded this data by adding other sections describing, among other things, the typology of dwellings, processing techniques, colouring, witness' names, seals, scales, coordinates related to the church building.

For better identification of the current state, the Index Sketches of the Stable Cadastre, capturing individual sites about 100 years later, were used. Based on the comparison with the present, we can find specific places on today's aerial photography. Of course, it should be noted that some of the sites have been significantly altered or completely disappeared and these maps have become the only evidence of settlement in the 18th century. (Ebelová, I., Paulus, F., Steinová, Š. et col.,2019)

\section{Different maps type}

Based on an analysis of the data obtained from the database, the authors of the study selected six examples, representing the possible variability of the maps. In terms of settlement typology, four models of urban and two village dwellings were selected. The urban structure and terrain layout were closely linked to the historical development and legal status of the site in question. The ground plan was determined by the landscape.

\subsection{Map of Rakovník}

The first map shows the orthogonal ground plan of the royal town of Rakovník, the inner structure of which consists of a rectangular square with a church and a street with rows of urban houses and gardens on the east side.

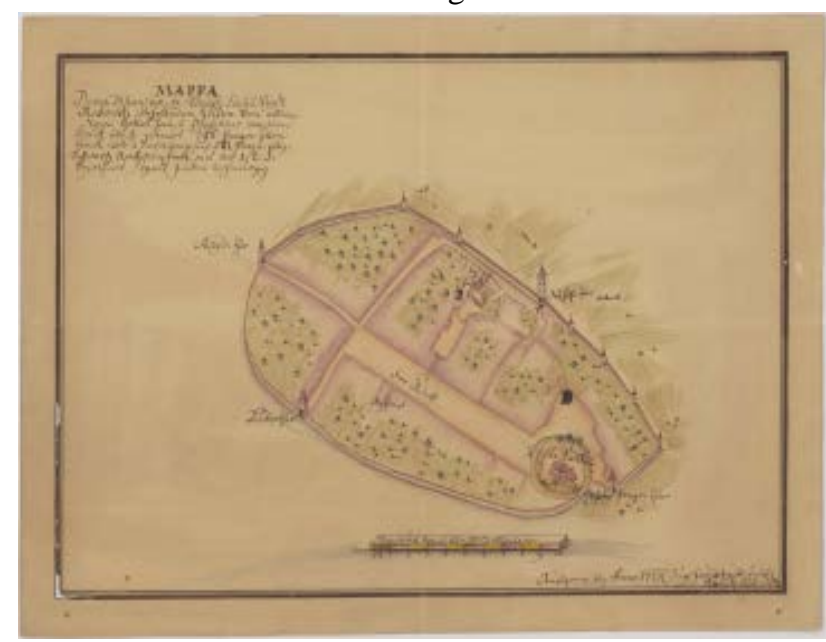

Figure 1. The hand-colored map of the town of Rakovník in 1727, depicting the town gates, the walls, and the floor plan of the Church of St. Bartholomew, the Town Hall and the Deanery. The author is the land surveyor Jan Josef Trübl. Scale 1:3045. National Archives of Prague, Collection of Maps and Charts, inv. no. 1080, sign. F/X/3.

This map shows the oldest depiction of the town of Rakovník, the beginnings of which can be traced back to the 13th century and which, over the years, has become a significant centre and also a regional town. The town with a system of fortifications broken up in several places by gates was captured by the land surveyor Trübl in perspective. No less distinct architectonic elements are the town Church of St. Bartholomew on the eastern side of the town and the Jewish quarter on the northern side of the town. In order to capture the distance between the church and the Jewish settlement, the land surveyor used Czech provincial (1 provincial $=30.82 \mathrm{~m}$ ), or Prague ell (1 Prague ell $=0.593 \mathrm{~m})$.

Other additional descriptive information includes the designation of the location of the Town Hall and the Dean's building. One of the confirmed hypotheses is the location of the fortified Church of St. Bartholomew on a hill surrounded by a moat with a group of trees and accessible by the bridge. 


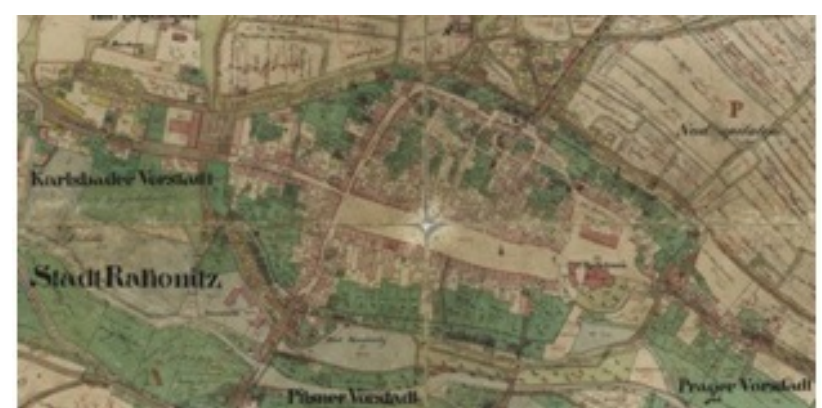

Figure 2. The Index Sketches of the Stable Cadastre portrayed Rakovník city dated 1841. National Archives of Prague, Stable Cadastre - Indication sketch Fund, Rak 280.

A sketch from the year 1841brings the same information as the map from 1727; however, in detail it differs, given the gradual demise of the town fortifications. Also visible is the destruction of the fortifications of the Church of St. Bartholomew documented on the hand-drawn map. There is no noticeable change in the Jewish settlement. (Ebelová, I., Paulus, F., Steinová, Š. et col.,2019)

\subsection{Map of Dolní Nýrsko}

The second example is a detailed plan of the feudal town of Dolní Nýrsko on the estate of Bystruice in the Pilsen region, from the land surveyor of Jan Nenader. The ground plan composition of the city situated on the righthand bank of the Úhlava river is a distinctive rectangular square, from which the individual streets run west and east. The square, surrounded by several urban houses, is completed with the Church of the Fourteen Holy Helpers in its centre. It was demolished in the 70s of the 20th century. The ground plan was influenced by the flow of the Úhlava River and a system of business routes in connection with the river crossing. A scattered settlement gradually formed along the river. In the southwest corner of the square there was a Jewish quarter consisting of a row of houses around two streets.

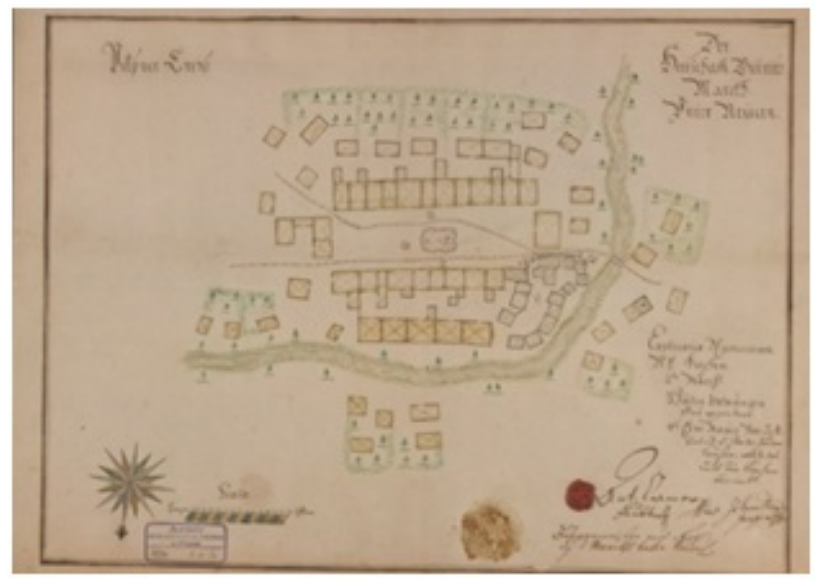

Figure 3. The hand-colored map of the town of Dolní Nýrsko from 1727 with a floor plan of the Church of the Fourteen St Helpers. Scale 1:1294. National Archives of Prague, Collection of Maps and Charts, inv. no. 1174, sign. A/XII/16.

The map depicts a separation wall between Jewish dwellings and Christian homes. On the other side of the river, near the Jewish Quarter, there is another Jewish dwelling. A sketch from the year 1837shows the same position as the map from 1727, including the placement of one Jewish structure across the river. There was no significant expansion of the Jewish population in Dolní Nýrsko during that time. (Ebelová, I., Paulus, F., Steinová, Š. et col.,2019)

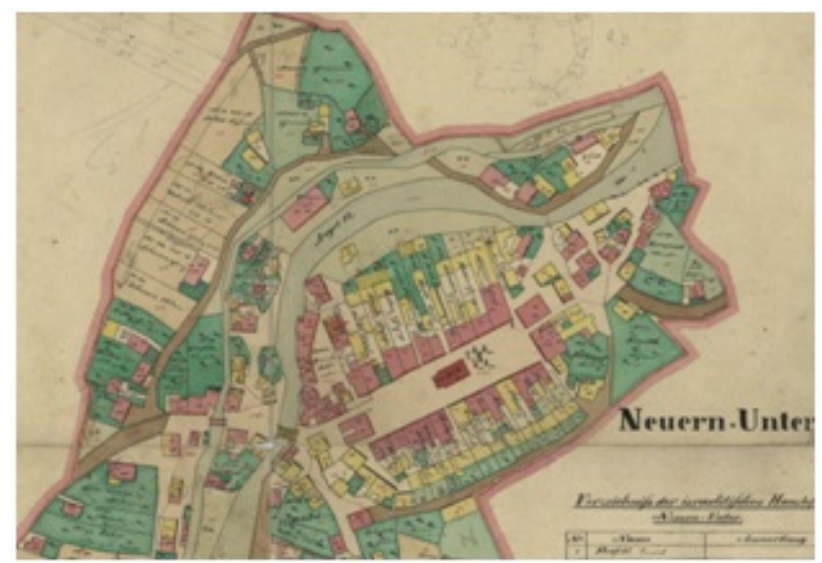

Figure 4. The Index Sketches of the Stable Cadastre portrayed Dolní Nýrsko city dated 1837. National Archives of Prague, Stable Cadastre - Indication sketch Fund, Kla 306.

\subsection{Map of Jirkov}

An unknown author of the prospective map of the feudal town of Jirkov placed the image into a yellow rectangular frame.

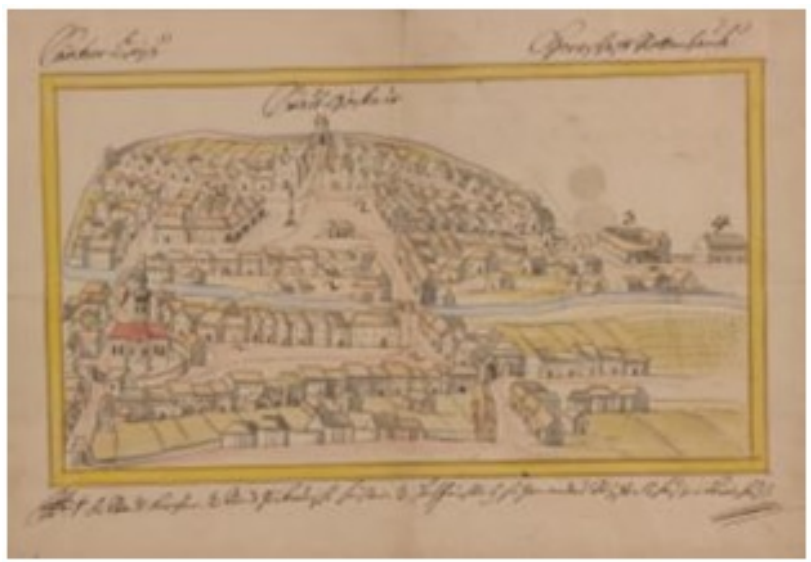

Figure 5. The hand-colored brochure of the town of Jirkov in Chomutov from 1727, depicting the Church of St. Jilje, a square with a town hall, the Virgin Mary's pillar, urban houses, town walls and gates, a river, bridges, a mill, and a brewery. The author is unknown. National Archives of Prague, a Collection of Maps and Charts, inv. no. 1138, sign. A/XI/5.

The preserved urban layout of the town centre, which was founded on the Czech-Saxon border, reveals the medieval foundation. The ground plan was influenced by the flow of the Bílina River and a system of the trade routes leading across the Ore Mountains to Saxony. The city consisted of two parts which had their own squares and were separated by the Bílina River; however, only in the southern part was the Church of St. Jiljí. Unlike the northern orthogonal square, which had a square base with outstretched streets in the corners, the southern square was created by a triangular system of fork-converging paths, with the Church of St. Jiljí being the dominant feature. Both parts were connected by two larger and one smaller bridge. In addition to the city fortifications broken up by a series of town gates and surrounding both 
parts, there is also a wall around the town church. Out of several objects it is possible to identify, for example, the town hall building with a tower, the mill with a mill wheel, and on the east side the brewery building and three Jewish houses. In this map the author did not use standard cartographic methods and therefore it lacks the scale and directional orientation. (Ebelová, I., Paulus, F., Steinová, Š. et col.,2019)

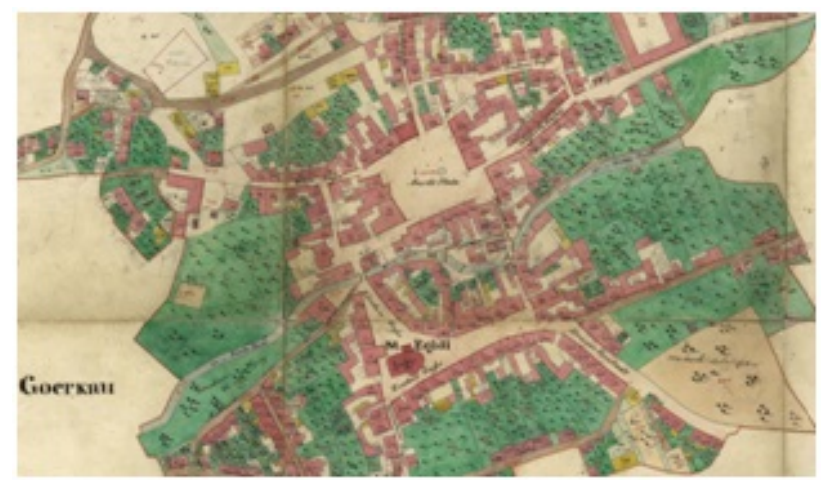

Figure 6. The Index Sketches of the Stable Cadastre portrayed town Jirkov dated 1842. National Archives of Prague, Stable Cadastre - Indication sketch Fund, Zat 64.

Although the map provides a perspective view of the town, these objects can be found in the sketch from the year 1842, apart from town walls that had already been torn down. Next to the church building, the town hall, the brewery, and the bridges can be seen.

\subsection{Map of Zbraslav}

Entirely different is a sketch depicting the locality of Zbraslav in the Beroun district, where the author, the land surveyor Jan Knittl, captured only the target objects without more detailed drawings of the immediate surroundings, as is evident from the other maps.

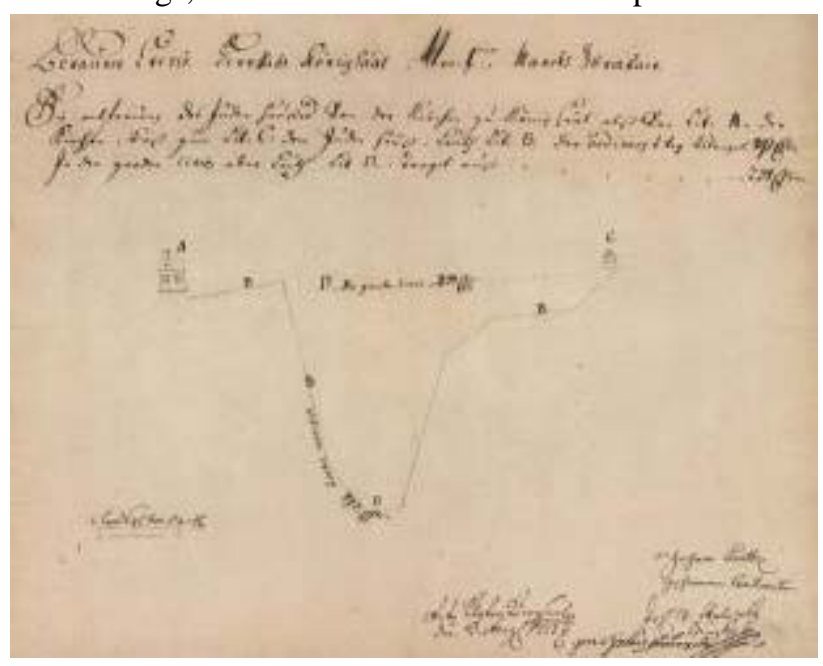

Figure 7. Positional sketch of the town of Zbraslav near Prague from 1727 with the location of the Church of St. Havel and the Jewish house. Scale 1:789. National Archives of Prague, Collection of Maps and Charts, inv. no. 1111, sign. F/XI/8.

The early medieval village, later promoted to a city, was originally situated at the confluence of the Berounka River and the Vltava River, before the flow of the Berounka River was altered. Originally a Romanesque, rebuilt as Baroque, single-nave church is situated to the west of the city centre on Havlín Hill. Knittl used two methods during the surveying. Using the first method he surveyed the straight line of the distance between the Church of St. Havel and the Jewish house in the city, and using the second, longer one, he copied the road to the city, including its changes in direction.

A sketch from the year 1840 captures the ground plan of the city with the Church of St. Havel and a road leading to centertown. However, the question remains whether a sketch can be used to locate the Jewish settlement. Knittl used the same technique for two other maps. (Ebelová, I., Paulus, F., Steinová, Š. et col.,2019)

\subsection{Map of Karlštejn castle and Budňany village}

This map combines two processing techniques, namely a cut-out with a colour ground plan of the site and a black-and-white perspective view of the valley village of Budnany. The floor plan of the royal castle Karlštejn is also part of the cut-out. A notable element on the ground plan is the flow of the river Berounka, on the left bank of which was the Church of St. Palmacius. The spatial planning of the village should be considered with regard to the modelling of the terrain of the valley, where the agricultural estates were connected by fields surrounded by forests. The connection with the valley was provided by a single road coming from the north, crossing a stream in one place, which is also evident in the perspective map. The author (the artist) and the land surveyor Jan Josef Dietzler used his knowledge in the field of art and captured individual objects in the smallest detail. Apparent are the gables, roofs, structures, farm buildings, including details of objects in the background of the map.

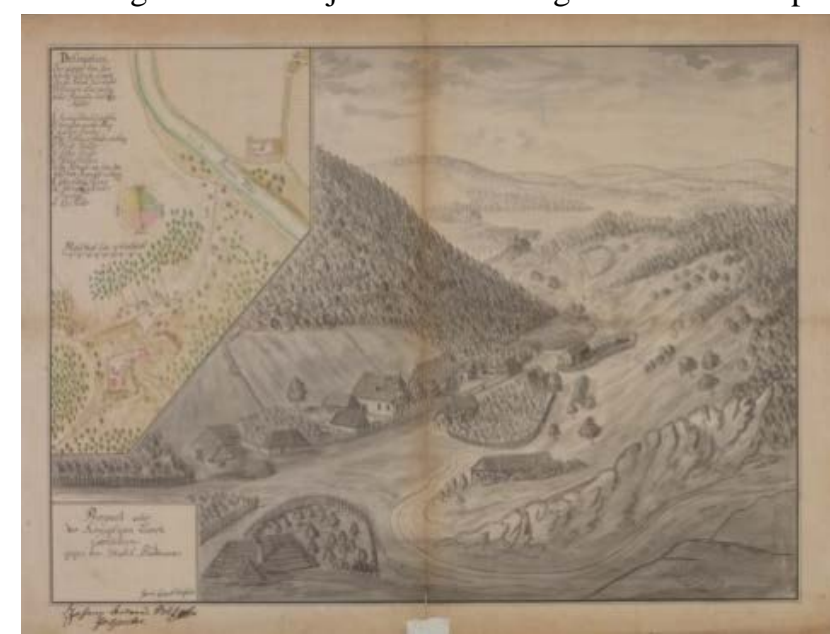

Figure 8. The colored manuscript map and view of the village Budnany in the Beroun district from 1727 with the picture of the Church of St. Palmacius, farmhouses with gardens and a ground plan of the Karlštejn Castle. Scale 1:5032. National Archives of Prague, Collection of Maps and Charts, inv. no. 1125 , sign. F/XI/22.

The likely position was around the Studniční Tower at the Karlštejn Castle. The author captured the date of the map on a rock on the right side of the image. In the centre of the village there is a Jewish settlement, which can also be found on the indication sketches of the Stable Cadastre from 1840. In this case, the representative sketch is 
showing the same condition as the ground plan of the map from 1727, including the mapping of the Karlštejn Castle and the Church of St. Palmacius. (Ebelová, I., Paulus, F., Steinová, Š. et col.,2019)

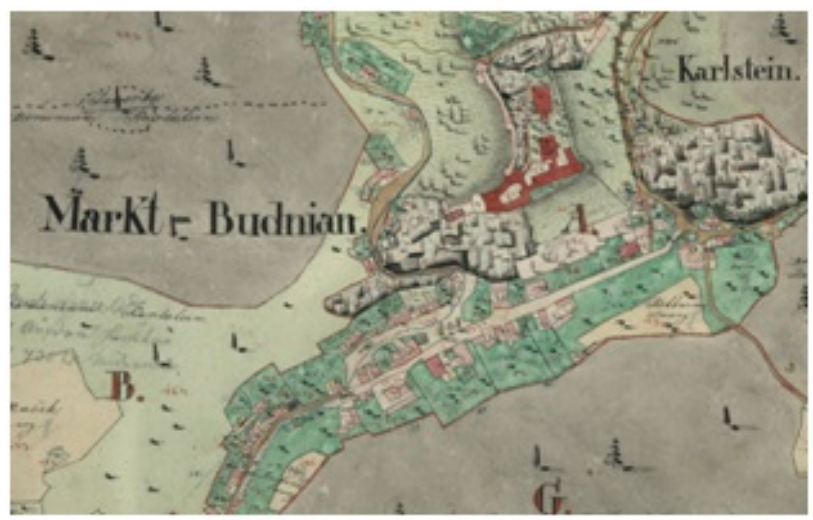

Figure 9. The Index Sketches of the Stable Cadastre portrayed Karlštejn castle dated 1840. National Archives of Prague, Stable Cadastre - Indication sketch Fund, Ber 45.

\subsection{Village of Liběchov}

The last presented illustration of the maps is the prospective map of the pharmacist Vojtěch J. Jankovský from Louny, who tried to capture the Baroque form of predominantly farm buildings in the village of Liběchov in the Mělník district. The urban layout of the village was influenced by the geomorphology of the terrain, where the Rumburk road rolled into the valley up the Dubsky ravine. The brochure is dominated by the red colour, indicating the roof tiles.

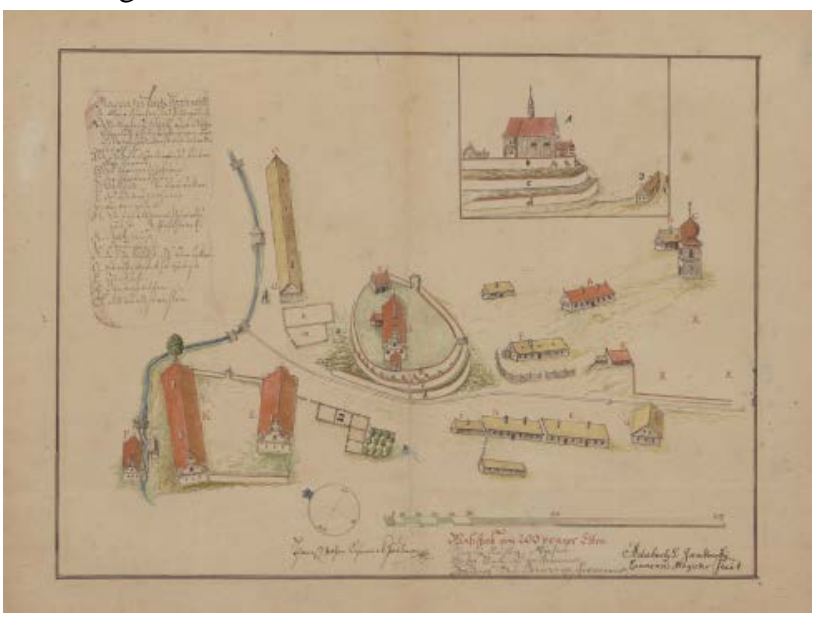

Figure 10. The coloured manuscript brochure of the village of Liběchov, depicting the Church of St. Havel (including details with terraces), a bell tower, a mill, a brewery, and a farm yard. Scale 1:700. National Archives Prague, Collection of Maps and Charts, inv. no. 1093, sign. F/X/16.

From the topographical point of view, we can identify farm objects (a mill, a brewery, a craft house, a farm yard) and religious objects (a church, a bell tower). The Jewish dwelling was captured by the author in a floor plan and in the cut-out. A display sketch from the year 1843 shows in this case the same condition as the view from 1727. (Ebelová, I., Paulus, F., Steinová, Š. et col.,2019)

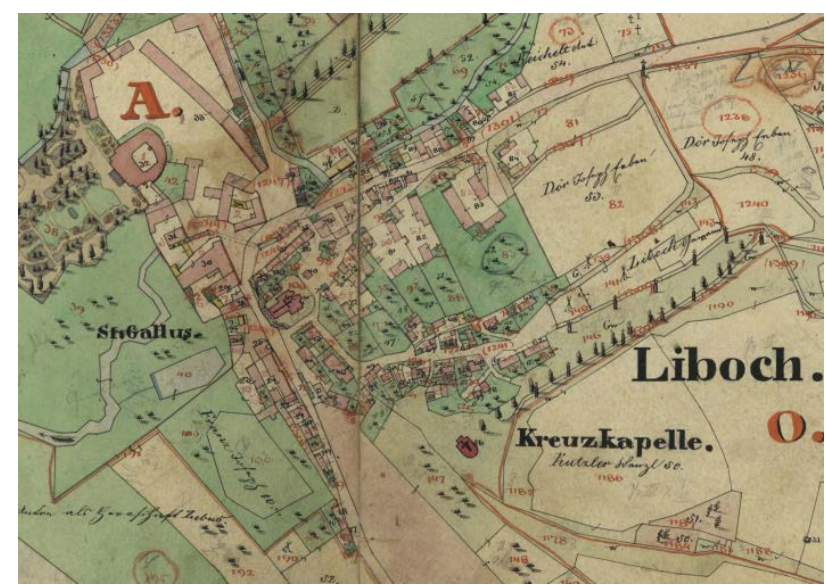

Figure 11. The Index Sketches of the Stable Cadastre portrayed Village of Liběchov dated 1843. National Archives of Prague, Stable Cadastre - Indication sketch Fund, Lit 264.

\section{Conclusions}

There is no doubt, the maps represent a set of extraordinary value, providing a reliable picture of the internal development of settlements and their topography, documenting the economic and social status of the Jewish population in the Czech lands. Based on a comparison with other sources, and above all the indicative sketches of a stable cadastre, it will, to a certain extent, monitor the development of Jewish settlement over a period of more than a century (until the middle of the 19th century). The proposed set of maps documents the economic and social status of the Jewish population in Bohemia, Moravia and Silesia. The preserved maps have a far wider significance with respect to the time of creation, content, form, origins, and external features for general, national or regional history. They provide a reliable picture of the internal development of settlements and their topography. Their use, however, lies not only in the cartography, but is used for the history of architecture and urbanism, in particular to identify small monuments, historical building styles, and to analyze the settlement structure, which is determined by natural and human factors. There is a distinction between urban and rural settlements, reflecting the different levels of economic development, contingent on influences from previous historical developments. It is evident, among other, in the capture of economic objects important for the economic management by the owners of the estate or the city. Equally important and yet completely neglected is the use for the history of landscaping and garden architecture, which brings new insights into today's extinct landscaping interventions and changes, preserved today only in relics or terrain inscriptions. In addition to the economic history, they are used for the history of art art history, history of cartography, ethnography, paper production, etc.

This is a unique collection of cartographic documents not only in the Czech Republic but, also throughout Europe. Maps capturing the Jewish population in municipalities and towns in the territory of one state department in the first half of the 18th century don't exist anywhere else. The significance of the set is also supported by the fact 
that smaller municipalities were captured in the given period, while for larger cities the plans are missing.

The uniqueness of this maps file is underlined by the fact that the file meets the criteria of UNESCO World Heritage.

\section{References}

Ebelová, I., Paulus, F., Steinová, Š. et col. (2019). The countryside and urbanism in the 18th century, handwritten plans. Translocation Plans for the Jewish Settlements in the lands of the Czech Crown in 17271728. (book in the press).

Legnerová, H. (2005). Unknown maps of Jewish settlement from the year 1727 from Mělník region. In: Porta Bohemica. Sborník historických prací 3. The State regional archives Litomerice, 2005, p. 292-298. Litoměřice, the Czech Republic.

Roubík, F. (1931). Maps of municipalities in the Czech Republic, with an indication of the Jewish homes dating from 1727. In: Časopis Společnosti přátel starožitností českých 39, 1931, s. 49-68. Prague, the Czechoslovak Republic.

Roubík, F. (1931). Die Judensiedlungen in Böhmen auf den Ortsplänen vom Jahre 1727. In: Jahrbuch der Gesellschaft für Geschichte der Juden in der Cechoslovakischen Republik 3, 1931, s. 283-306. Prague, the Czechoslovak Republic.

Roubík, F. (1961). Manuscript maps from 16th century to mid-18th century in the State Central Archives in Prague. In: Sborník archivních prací 11, 1961, s. 138186. Prague, the Czechoslovak Republic. 